\title{
The effect of indigestible dextrin and phytosterol on serum LDL-cholesterol level on hypercholesterolemic subjects
}

\author{
Anna H. Then ${ }^{1}$, Saptawati Bardosono ${ }^{1}$, Indriati P. Harahap ${ }^{2}$ \\ ${ }^{1}$ Nutrition Department, Faculty of Medicine, University of Indonesia, Jakarta \\ ${ }^{2}$ Biochemistry Department, Faculty of Medicine, University of Indonesia, Jakarta
}

\begin{abstract}
Abstrak
Tujuan Membandingkan efek pemberian indigestible dextrin $2 x 2.3 g$ /hari (ID) dan fitosterol $2 x 0.6 g /$ hari (FS) selama 6 minggu dalam menurunkan kadar kolesterol-LDL pada pasien hiperkolesterolemia
\end{abstract}

Metode Menggunakan rancangan studi uji klinis pada dua kelompok pararel tersamar ganda dengan alokasi random pada 16 subyek per-kelompok.

Hasil Sebelum intervensi, kadar kolesterol-LDL pada kelompok ID dan kelompok FS masing-masing adalah 158,81 $\pm 17,74 \mathrm{mg} / \mathrm{dL}$ and $176,18 \pm 25,31 \mathrm{mg} / \mathrm{dL}$. Setelah intervensi, didapatkan penurunan kadar kolesterol-LDL yag bermakna pada kedua kelompok, yaitu masing-masing sebesar 20,93 $\pm 12,65 \mathrm{mg} / \mathrm{dL}$ (13.24\%) dengan nilai P $<0.001$ pada kelompok $I D$, dan 21,87 $\pm 28,76 \mathrm{mg} / \mathrm{dL}(11,21 \%)$ dengan nilai $P=0.008$ pada kelompok $F S$. Namun besarnya penurunan tersebut tidak berbeda bermakna antar kedua kelompok.

Kesimpulan Penurunan kadar LDL-kolesterol pada pasien hiperkolesterolemia yang mengonsumsi indigestible dextrin 2x2.3g/hari selama 6 minggu tidak berbeda dengan mereka yang mengonsumsi fitosterol $2 \times 0.6 \mathrm{~g} / \mathrm{hari}$ selama 6 minggu. (Med J Indones 2009; 18: 114-9)

\begin{abstract}
Aim To investigate the effects of indigestible dextrin $2 \times 2.3 \mathrm{~g}$ /day and phytosterol $2 \mathrm{x} 0.6 \mathrm{~g} /$ day provided for 6 weeks in lowering serum LDL-cholesterol levels amongs hypercholesterolemic subjects.

Methods A randomized clinical trial, two pararel groups, double blinded and randomly assigned to each different group was done in 16 subjects per-group.

Results Before the, intervention the level of LDL cholesterol of both ID and FS group were $158.81 \pm 17.74 \mathrm{mg} / \mathrm{dL}$ and $176.18 \pm 25.31 \mathrm{mg} / \mathrm{dL}$, respectively. After the intervention there was a significant reduction in LDL cholesterol level in both groups, i.e. among the ID group by $20.93 \pm 12.65 \mathrm{mg} / \mathrm{dL}(13.24 \%)$ with $\mathrm{p}$ value of $<0.001$, while the reduction of LDL cholesterol level among the PS group was $21.87 \pm 28.76 \mathrm{mg} / \mathrm{dL}(11.21 \%)$ with p value of 0.008 . However, the reduction of cholesterol level between the two groups did not show any significant difference.
\end{abstract}

Conclusion Consuming indigestible dextrin $2 \times 2.3 \mathrm{~g} /$ day and $2 \times 0.6 \mathrm{~g} /$ day phytosterol (PS) for 6 weeks will have the same ability to decrease the serum cholesterol level in hypercholesterolemic subjects. (Med J Indones 2009; 18: 114-9)

Key words: indigestible dextrin, phytosterol, cholesterol

In Indonesia, hipercholesterolemia is starting to be evidence at the age group of 25 to 34 years old. ${ }^{1}$ It is widely known that coronary heart disease (CHD) is still the major cause of death in the world. The main risk factor of CHD is hypercholesterolemia ${ }^{2}$. Besides genetic factor, other causes of hypercholesterolemia among others is high prevalence of cholesterol-high fat diet, obesity, aging, menopause, several diseases and the use of certain drugs. ${ }^{2}$

The management of hypercholesterolemia according to NCEP - ATP III, 2001 is through Therapeutic Lifestyle
Changes (TLC), which consists of changes in life style, and TLC diet with recommendation to increase the intake of fiber up to $20-30 \mathrm{~g} /$ day and phytosterol of 2 $\mathrm{g} /$ day. ${ }^{3}$ Indigestible dextrin (ID) is a starch hydrolyzed that synthesized from corn starch, acting as soluble fiber, had a hypercholesterolemia effect. ${ }^{4}$ Administration of $5.5 \mathrm{~g}$ /day of ID for 8 weeks reduced triglyceride level significantly ${ }^{5}$ and administration of $3 \times 10 \mathrm{~g} /$ day of ID for 3 months significantly reduced serum total cholesterol and triglyceride level. ${ }^{6}$ While, phytosterol (PS) is a plant sterol that had a similar structure and function as cholesterol in human but with different side chains. ${ }^{7}$ 
Administration of $1.2 \mathrm{~g}$ /day and $1.6 \mathrm{~g} /$ day phytosterol in low fat milk, reduced serum cholesterol LDL level $7.13 \%$ and $9.5 \%$ respectively. ${ }^{8}$

The major effect of fiber intake is through the disturbance of the enterohepatic circulation by binding bile acid and cholesterol in the lumen of intestine and then excreted in the stool. This result in the reduction of intrahepatic cholesterol concentration, then substantially stimulated HMG CoA reductase and CYP 7 activity resulting in increased of compensatory cholesterol and bile acid synthesis. Reduction of intrahepatic cholesterol concentration will increase the synthesis of LDL receptor. The reduction of chilomicron remnant will decrease VLDL synthesis, and result in the reduction of VLDL conversion to LDL. 9,10

On the other hand, intake of phytosterol (PS) will decreased the cholesterol absorption in intestinal lumen through various mechanisms. The most important of which is that PS as a ligand for the nuclear receptor LXR - RXR. Activation of nuclear receptor increases synthesis of target gen, adenosine-tri-phosphate binding cassette $(\mathrm{ABC}) \mathrm{A} 1$, that could efflux cholesterol out of enterocyte. This mechanism substantially lowered serum LDL cholesterol concentration. ${ }^{11,12}$

The objective of this study is to compare the effects of indigestible dextrin $2 \times 2.3 \mathrm{~g} /$ day and phytosterol $2 \times 0.6 \mathrm{~g} /$ day for 6 weeks on serum LDL cholesterol level in hypercholesterolaemic subjects.

\section{METHODS}

\section{Subjects}

Subjects were hypercholesterolaemic patients who were recruited by public advertisements calling particularly for whom with known elevated total cholesterol concentrations. Subjects were screened on the following selection criteria: 1) men and women, aged $25-55 \mathrm{y}, 2$ ) body mass index $\geq 18.5 \mathrm{~kg} / \mathrm{m}^{2}$, 3) total cholesterol concentration $200-300 \mathrm{mg} / \mathrm{dL}$, 4) with the absence of diabetes, renal disease, obstructive liver disease, or hypothyroidism, 5) not taking medications that affect lipid metabolism and 6) not in lactating or pregnancy conditions.

Fourthy two subjects met research criteria, and were then randomly alocated into two groups by block randomistion (21subjects/group). After the one week run-in periode, subjects were assigned to received
$2 \times 2.3 \mathrm{~g} /$ day ID and $2 \times 0.6 \mathrm{~g} /$ day FS in a double blind manuer. The study proposal was approved by The Ethics Commitee of the Faculty of Medicine University of Indonesia. All subjects received both written and oral information regarding the study and gave their written consent.

\section{Study design}

The study was a randomized clinical trial, two parallel groups, doubleblindedandrandomlyassignedtoinvestigate the effects of indigestible dextrin and phytosterol on the cholesterol LDL level of hypercholesterolemia subjects. The investigation was done at the Clinical Nutrition Department of Faculty of Medicine University of Indonesia at Salemba Raya no 6, Jakarta from July 2006 to October 2006.

The study was done in three periode:

1. Pre-intervention period (week 0 -week 1)

Data obtained through interview, including demographic data, physical activity indexs, intake pattern by semiquantitative food frequency questionaire (FFQ). Anthropometric measurement including body weight, body height and waist circumfrance Subjects were allowed to eat their habitual diet for one week (run-in periode) and fullfilled the food diary with the portion size that were estimated using a validated portion size picture booklet.

2. Intervention period (week 1- week 6) Before starting the intervention periode, all subjects underwent blood check for serum LDL cholesterol concentration after an overnight fasting for 12-14 hours.Subjects were examined for baseline food intake by $2 \times 24$ hours food recall, physical activity index and anthropometry that were repeated every two weeks. Study product were consumed for six weeks and distributed to each subjects every two weeks. Every two weeks subjects visit The Nutrition Department to get nutrition counseling and to return any unconsumed product, including the empty product packaging.

3. Post intervention period

At the end of week 6 , all subjects underwent blood check for serum LDL cholesterol concentration after an overnight fasting for 12-14 hours.Food intake, physical activity index and anthropometric measures were also evaluated.

\section{Diet}

All subjects followed a low-fat diet recommended by the National Cholesterol Education Program Adult 
Treatment Panel III 2001 (TLC diet) in which the compositions of the diet were in accordance to the hypercholesterolaemic diet PERKENI 2005. The planned composition of the diet was: energy from fat as $20-25 \%$ of total energy requirement, carbohydrate as $50-60 \%$ of total energy requirement, protein as $10-$ $15 \%$ of total energy requirement, $<200 \mathrm{mg}$ /day dietary cholesterol, $\geq 30 \mathrm{~g}$ /day fibre, from five portions/day fruits and vegetables. The energy requirement of each subject was estimated using the Harris Benedict formula with the energy requirement due to physical activity added.

\section{Laboratory Measurement}

Venous blood samples were obtained after 12-14 h overnight fast by using standardised methods. Enzymatic photometric methods were used for the determination of serum LDL cholesterol (CHODP-PAP).

\section{Statistical Analysis}

All statistical analyses were performed with SPSS for windows version 11.5. Data were expressed as mean \pm SD for normal distributed data and median (minimummaximum) for the not normal distributed data.

Normality of the data distribution was checked using Kolmogorov-Smirnov test before underwent further analysis. Two-tailed comparisons with independent $t$ test or Mann-Whitney test were used to compare two mean between the two groups. Two-tailed paired $t$ test or Wilcoxon were used to compare the before-after mean in each group. Power of the study was 0.90 based on assumption to be able to detect a $13.44 \mathrm{mg} / \mathrm{dL}(0.34$ $\mathrm{mmol} / \mathrm{L}$ ) difference in serum LDL cholesterol and probability for type I error $\alpha=0.05$.

\section{RESULTS}

\section{Subjects and compliance}

There were 42 subjects recruited into the study, 18 subjects for each group completed the study period, but 2 subjects from each group were excluded due to the less than $70 \%$ compliance, therefore 16 subject for each group were analized.

\section{Baseline characteristic}

Data were obtained by interview for demography, physical activities index, intake pattern and food intake before and after intervention, and physical activity index. Nutritional status was determined using antropometrics measurement, and serum LDL cholesterol was determined as the outcome of the study.
Subjects consisted of 14 male and 18 female with average age of $44.44 \pm 7.28$ years for ID group and $40.75 \pm 7.65$ years for PS group. Most of the subjects have medium to high education level. Before the interventions, the average BMI was $26.98 \pm 3.36 \mathrm{~kg} / \mathrm{m}^{2}$ and $27.82 \pm 4.03 \mathrm{~kg} / \mathrm{m}^{2}$ for ID and PS group subjects respectively. Both groups were categorized as obese I, and based on their waist measurement, $50 \%$ of the male subject and $83.25 \%$ of female subjects are categorized as having central obesity (table 1).

Table 1. Antrophometrics characteristics of the study population at baseline

\begin{tabular}{lcc}
\hline $\begin{array}{l}\text { Subject's } \\
\text { Characteristics }\end{array}$ & $\begin{array}{c}\text { ID group } \\
(\mathrm{n}=16)\end{array}$ & $\begin{array}{c}\text { PS group } \\
(\mathrm{n}=16)\end{array}$ \\
\hline Body weight $(\mathrm{kg})$ & $70.01 \pm 10.50$ & $68.23 \pm 8.13$ \\
BMI $\left(\mathrm{kg} / \mathrm{m}^{2}\right)$ : & $26.98 \pm 3.36$ & $27.82 \pm 4.03$ \\
Categorized BMI\# & & \\
$(\mathrm{n}, \%)$ & $2(12.5)$ & - \\
$-18.5-22.9$ & $2(12.5)$ & $3(18.75)$ \\
$-23.0-24.9$ & $8(50.0)$ & $11(68.75)$ \\
$-25.0-29.9$ & $4(25.0)$ & $2(12,5)$ \\
$->30$ & & \\
& & $89.23 \pm 5.99$ \\
Waist circumference & $87.10 \pm 8.90$ & \\
$(\mathrm{~cm}) \#:$ & & $3(18.75)$ \\
For male $(\mathrm{n}, \%)$ & $4(25.0)$ & $5(31.25)$ \\
$\quad<90 \mathrm{~cm}$ & $2(12.5)$ & $1(6.25)$ \\
$\geq 90 \mathrm{~cm}$ & & $7(43.75)$ \\
For female & $2(12.5)$ & \\
$<80 \mathrm{~cm}$ & $8(50.0)$ & \\
$\geq 80 \mathrm{~cm}$ & & \\
\hline
\end{tabular}

\#Based on WHO-WRPO for Asia -Pacific

\section{Nutrient intakes}

Based on calorie intake pattern, both groups had calorie intake more than $120 \%$ of total calorie requirement (TCR), protein intake $>15 \% \mathrm{TCR}$, fat intake was $52 \%$ TCR in ID group and 49\% TCR in PS group, carbohydrate intake was $>60 \% \mathrm{TCR}$, cholesterol intake was $>200 \mathrm{mg} /$ day, while the average of fiber intake was $<30 \mathrm{~g} /$ day and phytosterol intake was $<2 \mathrm{~g}$ /day.

Before the intervention, the average of calorie intake of the ID group was sufficient, while after the intervention there were decreases in the average intake of fat, carbohydrate, and cholesterol. On the other hand in PS group, before the intervention, the average calorie intake, and the average intakes of fat, protein, carbohydrate, cholesterol and fiber were deficient. After intervention there were no difference between the two groups (Table 2). 
Table 2. Nutrient intake pattern, nutrient intake before and after intervention in percentage of total calorie requirement (TCR)

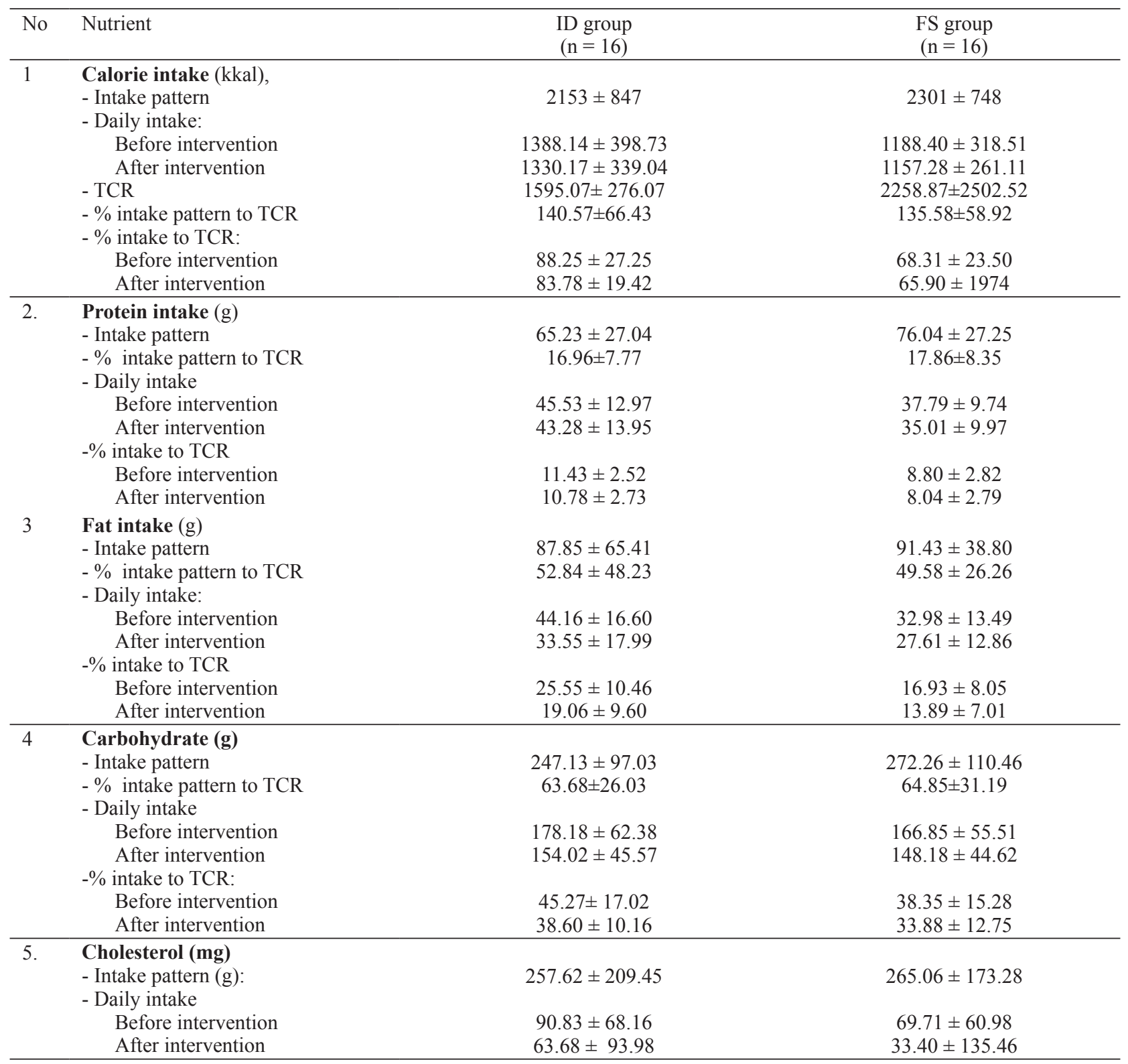

TCR: total calorie requuirement, ID: indigestible dextrin, PS: phytosterol

\section{Subjects LDL cholesterol levels}

Before the, intervention the level of LDL cholesterol of both ID and FS group were $158.81 \pm 17.74 \mathrm{mg} /$ $\mathrm{dL}$ and $176.18 \pm 25.31 \mathrm{mg} / \mathrm{dL}$, respectively. After the intervention there was a significant reduction in LDL cholesterol level among the ID group by $20.93 \pm$ $12.65 \mathrm{mg} / \mathrm{dL}$ (13.24\%) with $p$ value of $<0.001$, while the reduction of LDL cholesterol level among the PS group was $21.87 \pm 28.76 \mathrm{mg} / \mathrm{dL}(11.21 \%)$ with $p$ value of 0.008 . The reduction of cholesterol level between the two groups did not show any significant difference. Mean subjects compliance for test product intake were $90.28 \pm 5.11 \%$ in ID group and $87.60 \pm 9.06 \%$ in PS group with the mean ID and PS intake were $4.09 \pm 0.33$ $\mathrm{g} /$ day and $1.04 \pm 0.10 \mathrm{~g} /$ day, respectively (Table 3 ). 
Table 3. Subjects LDL cholesterol level before and after intervention

\begin{tabular}{lcccc}
\hline & $\begin{array}{c}\text { ID group } \\
(\mathrm{n}=16)\end{array}$ & $\begin{array}{c}\text { FS group } \\
(\mathrm{n}=16)\end{array}$ & Difference & $\begin{array}{c}\mathrm{p} \\
\text { Value* }\end{array}$ \\
\hline $\begin{array}{l}\text { LDL } \\
\text { cholesterol } \\
(\mathrm{mg} / \mathrm{dL}):\end{array}$ & & & & \\
- Before & $158.81 \pm 17.74$ & $176.18 \pm 25.31$ & & \\
- After & $137.85 \pm 20.64$ & $154.31 \pm 25.10$ & $16.43 \pm 8.12$ & \\
- Difference & $20.93 \pm 12.65$ & $21.87 \pm 28.76$ & $0.93 \pm 7.85$ & NS \\
- Percentage & $13.24 \pm 8.22$ & $11.21 \pm 17.21$ & $2.03 \pm 4,77$ & NS \\
- p value** & $<0.001$ & 0.008 & &
\end{tabular}

*unpaired $t$ test; $* *$ paired $t$ test; $\mathrm{NS}$, not significant $(\mathrm{P}>0.05)$

\section{DISCUSSIONS}

In this two pararel groups intervention study, the effects of ID as soluble fiber and phytosterol in lowering LDL cholesterol levels among the hypercholesterolemic subjects, shows a significant reduction after the intervention in each group. However, there was no significant difference in those changes between the two groups.

Before the intervention the level of LDL cholesterol in both ID and FS group were $158.81 \pm 17.74 \mathrm{mg} /$ $\mathrm{dL}$ and $176.18 \pm 25.31 \mathrm{mg} / \mathrm{dL}$, respectively. After the intervention there was a significant reduction in LDL cholesterol level among the ID group (158.81 \pm 17.74 $\mathrm{mg} / \mathrm{dL}$ to $137.85 \pm 20.64 \mathrm{mg} / \mathrm{dL}$ ) or a reduction of $20.93 \pm 12.65 \mathrm{mg} / \mathrm{dL}(13.24 \%)$ with $\mathrm{p}$ value of $<0.001$. The two test products have different in mechanism in decreasing the LDL cholesterol.

The major effect of ID as soluble fiber is through the reduction in intrahepatic cholesterol due to the conversion of cholesterol to bile acid. ${ }^{10}$ Soluble fiber disturbs the enterohepatic circulation by binding bile acid and cholesterol in the lumen of intestine and then excreted in the stool ${ }^{9,10}$ Thus resulting in the reduction of intrahepatic cholesterol concentration, substantially stimulating HMG CoA reductase and CYP 7 activity to increase the compensatory cholesterol and bile acid synthesis. Reduction of intrahepatic cholesterol concentration will increase the synthesis of LDL receptor. ${ }^{11}$ The reduction of chilomicron remnant will decrease VLDL synthesis, and so to reduction of VLDL conversion to LDL. ${ }^{9}, 10$

On the other hand, PS has several mechanisms in lowering LDL cholesterol levels. ${ }^{12}$ The most important mechanism was PS as a ligand for LXR - RXR nuclear reseptor. $^{12,13}$ The heterodimer LXR - RXR regulates several genes involved in the synthesis, absorption, excretion of cholesterol homeostasis and lipoprotein metabolism, including increased expression of $\mathrm{ABC}$ genes (adenosine-tri-phosphate binding cassette) AI, a transporter which effluxes cholesterol from enterocyte, hepatocyte, macrophage, and ABC-G5 and G8 transporter that effluxes cholesterol from hepatocyte to bile sac. ${ }^{12}$ High Intracellular PS level will also be sensed by other sensor such as SREBP - 2, which inhibit the combining of SREBP - 2 and SRE, resulting in reduction in HMG Co A reductase synthesis, and thus cholesterol synthesis will be hampered. The low intracellular cholesterol level resulted reduction in formation of chilomicron. ${ }^{13}$ Chilomicron remnant reaching the liver will be decreased; and this condition will stimulate the synthesis of LDL receptor. Besides, the reduction of VLDL secretion of the liver cells will result in reduction of VLDL conversion to LDL. The end result will be a lowering level of LDL. ${ }^{14}$

In this study, based on the LDL cholesterol lowering mechanism, PS should be more capable then ID because PS would act directly into the mechanism that regulated cholesterol homeostasis. In fact the lowering effects of ID was bigger then PS, $13.24 \%$ vs $11.21 \%$. This maybe due 1) to the lower LDL cholesterol level at baseline in ID group as compared to the PS group, and 2) the effects of counseling according to changing of eating habit as recommended by the NCEP-ATP III, 2001.

Before the, intervention the level of LDL cholesterol of both ID and FS group were categorized as "borderline high" and "high", respectively. After the intervention there was a significant reduction in LDL cholesterol level among the ID group, but still categorized as "borderline high", while the reduction of LDL cholesterol level among the PS group could be categorized as "borderline high. High LDL cholesterol level are related to high cardiovascular (CVD) risk factor, on the other hand optimal LDL cholesterol level may have low CVD risk factor.

Mean subjects adherence for test product intake were $90.28 \pm 5.11 \%$ in ID group and $87.60 \pm 9.06 \%$ in PS group. Mean ID and PS intake were $4.09 \pm 0.33 \mathrm{~g}$ /day and $1.04 \pm 0.10 \mathrm{~g} /$ day respectively.

Consuming indigestible dextrin $2 \times 2.3 \mathrm{~g} /$ day and $2 \times 0.6 \mathrm{~g} /$ day phytosterol (PS) for 6 weeks, showed similar ability to decrease serum LDL cholesterol level in hypercholesterolemic subjects. 


\section{REFFERENCES}

1. Survei Kesehatan Rumah Tangga (SKRT) (2004) Status kesehatan masyarakat Indonesia, dalam Survei Kesehatan Nasional Soemantri S., Budiarso L.R., dan Sandjaja eds. Badan Penelitian dan Pengembangan Departemen Kesehatan Republik Indonesia, Jakarta. 2004; 2: 34-6.

2. Grundy S. M. Nutrition in the management of disorder of serum lipids and lipoprotein in Modern Nutrition in Health and Disease, $10^{\text {th }}$ ed, Lippincott William \& Wilkin, Baltimore: 2006; p 1076-94.

3. Third Report of the National Cholesterol Education Program (NCEP) Expert Panel on Detection, and Treatment of High Blood Cholesterol in Adult (Adult Treatment Panel III), 2001. Circulation 17/24, 2002.

4. Okhuma K dan Wakabayashi S. Fbersol-2: soluble, non digestible, starch derived dietary fiber in (McCleary dan Prosky L. eds), Advanced Dietary Fiber Technology, Blackwell Science, Oxford, UK: 2001; p 509-23.

5. Kajimoto O, Henmi M, Sano J, Tsuda R, Hatori M, Ohki $\mathrm{K}$, et al. Effect of tea beveraege containing indigestible dextrin on the serum trigleseride level insubjects with mild hipertrygliseridemia. J. Nutritional Food, 2002; 5: 117-30.

6. Kishimoto Y, Wakabayashi S, and Tokunaga K, Effect of long-term administration of indigestible dextrin on visceral fat accumulation. J. Jpn. Assoc. Dietary Fiber Res. 2000; 4: 59-65

7. Piironen V, Lindsay DG, Mietinnen TA, Toivo J. and Lampi AM. Review, Plant sterol: biosynthesis, biological function and importance to human nutrition. J. Sci. Food Agric. 2000; 80: 939-66.

8 Thomsen A.B., Hansen H.B., Christiasen C., Green H. and Berger A. Effect free plant sterols in low fat milk on serum lipid profile in hipercholesterolemic subjects. European Journal of Clinical Nutrition, 2004; 58: 860-70.

9. Fernandez M.L. Soluble fiber and nondigestible carbohydrate effects on plasma lipids and cardiovascular risk. Curr. Op. Lipidol. 2001; 12: 35-40.

10. Kishimoto $\mathrm{Y}$, Wakabayashi $\mathrm{S}$, and Takeda $\mathrm{H}$. Hipocholesterolemic effect of dietary fiber: Relation to intestinal fermentation and bile acid excretion. J. Nutr. Sci. Vitaminol; 1995; 41: 151-61.

11. Trautwein EA and Duchateau GSMJE. Awad AB and Bradford PG, eds. Phytosterols: sources and metabolism in Nutrition and Cancer Prevention, CRC, Taylor and Francis group. 2006; p 223-41.

12 Brousseau ME. ATP-binding cassette transporter A1, fatty acids, and cholesterol absorption. Current Opinion in Lipidology. 2003; 14: 35-40.

13. Mayes. Cholesterol synthesis, transport and excretion. In Murry RK, Granner DK, Mayes PA. and Rodwell VW, eds. Harpes Biochemistry. Mc Graw-Hill : 2000; p. 285-97.

14. Trautwein EA, Duchateau GSMJE, Lin Yuguang, Melnikov SM, Molhuizen HO, Ntanioa F. Proposed mechanism of cholesterol lowering action of plant sterols. Eur. J. Lipid Sci.Technol. 2003; 105: 171-85.

15. Plat J. and Mensink RP. Increased intestinal ABCA1 expression contributes tothe decrease on cholesterol absorption after plant stanol consumption. FASEB J. 2002; 16:1248-53.

16. Ginsberg $\mathrm{HN}$ and Karmally W. Nutrition, Lipids, and Cardiovascular Disease in Biochemical and Physiological Aspect of Human Nutrition in Stipanuk MH, ed. Saunders Company, Philadelphia, Pennsylvania: 2000; p. 917-44. 